\title{
Perspectives on Biological Treatment of Tannery Effluent
}

\section{Sabumon PC}

School of Mechanical and Building Sciences, VIT University, Chennai, Tamil Nadu, India

\begin{abstract}
Leather processing is an important economic activity around the world and uncontrolled release of tannery effluents to natural water bodies causes environmental degradation and increases health risks to human beings. The treatment of tannery effluent is a complex technological challenge because of the presence of high concentrations of organic and inorganic pollutants of both conservative and non conservative nature. In this review paper information relevant to tannery effluents and its prospective on biological treatment processes and other recent potential biological processes are discussed. Emphasis is laid on the removal of organic matter (COD/BOD), $\mathrm{NH}_{4}-\mathrm{N}$ and sulphide/sulphate from tannery effluent. Though the aerobic process is efficient in treating tannery effluent, it requires an extended aeration time at low organic loading rates and thereby increasing the overall treatment cost. Anaerobic process is not effective because of sulphide inhibition problems. Sulphide inhibition control is essential for successful anaerobic treatment of tannery effluent. Sequencing Batch Reactor (SBR) and membrane reactor technologies are found to be effective for removal of organic matter and ammonia, but they are having very high operational cost. A recent development is the employment of alternate electron acceptor/donor already present in tannery effluent for simultaneous removals of $\mathrm{COD} / \mathrm{BOD}, \mathrm{NH}_{4}-\mathrm{N}$ and sulphide/sulphate with possibility of elemental sulphur recovery at higher organic loading rates. The recent development shows possibility of high rate treatment of tannery effluent in an alternate and an effective way suitable to both developing and developed countries.
\end{abstract}

Keywords: Tannery effluent; Biological treatment; Sulphate; Sulphide; Sulphidogenesis; Anoxic ammonia removal

\section{Introduction}

Leather processing is an important economic activity in many developing and developed countries. It has been estimated that the annual production of leather in the entire world is approximately 1.67 billion $\mathrm{m}^{2}$, with an estimated trade value of US\$ 70 billion. South Asia meets approximately $20 \%$ of world's needs [1]. Since most of the developing countries are using the traditional leather processing, the characteristics of effluent are similar. Tanneries in India are categorized as small (approximately $80 \%$ ), medium (approximately 15\%) and large-scale [2]. These tanneries are mainly located in the states of Tamilnadu, Karnataka, Andhra Pradesh, Rajasthan, Punjab, Utter Pradesh and West Bengal [3]. The tannery effluent produced from traditional or conventional leather processing contains a high concentration of organics (COD/BOD), Suspended Solids (S.S) and inorganics like $\mathrm{NH}_{4}-\mathrm{N}, \mathrm{SO}_{4}^{2-} / \mathrm{S}^{2-}, \mathrm{Cr}$ (III) and Chlorides [4-6]. Uncontrolled release of tannery effluents to natural water bodies causes environmental degradation and increases health risks to human beings [7]. The environmental degradation caused is depletion of dissolved oxygen in streams/rivers, eutrophication of water bodies, toxicity to fishes and other aquatic flora and fauna [8,9]. Moreover, local inhabitants are suffering from water borne diseases associated with water pollution, e.g., gastroenteritis, hyperchloremic acidosis, hypertension, arteriosclerosis, cardiac arrest, retinal toxicity, hepatic fibrosis, hepatocellularcancer, diabetes, sperm damage, feto-maternal death, and impaired neurobehavioral functions [10]. Hence, appropriate treatment of effluent is required prior to its discharge into the environment [5]. For complete treatment of tannery effluent; primary, secondary and tertiary treatments are necessary. Primary treatment removes S.S, Chromium, Oil and Grease. Secondary treatment is normally employed for removal of pollutants using biological processes by oxidative-reductive processes. Tertiary treatment is required when color, refractory organic compounds and salts are to be removed and generally expensive physic-chemical treatments techniques are employed. As per the very recent directive of Central Pollution Control Board (CPCB), New Delhi, India, tanneries are required to meet zero liquid discharge (ZLD) norms because of the potential threat to environment and human beings by the discharge of tannery effluents. This directive has prompted tanneries to adopt advanced treatment techniques after secondary treatment to make the treated water re-usable in the tanneries.

In this review paper information relevant to tannery effluents and its prospective biological treatment processes and other recent potential biological processes are discussed. Emphasis is laid on the removal of organic matter (COD/BOD), $\mathrm{NH}_{4}-\mathrm{N}$ and sulphides/sulphates. Finally, a recent development by employing alternate electron acceptors/ donors already present in tannery effluent for simultaneous removal of $\mathrm{COD} / \mathrm{BOD}, \mathrm{NH}_{4}-\mathrm{N}$ and sulphides/sulphates with possibility of sulphur recovery is included. The recent development shows possibility of high rate treatment of tannery effluent in an alternate and an effective way.

\section{Pollution potential of tanneries}

In the leather tanning process, a series of chemical treatments are performed by applying a large number of chemicals such as surfactants, acids, dyes, natural or synthetic tanning agents, sulfonated oils, and salts to transform animal skin into an unalterable and imputrescible product. Considering the large amounts of chemicals applied, and the low biodegradability of these chemicals, tannery effluent treatment is a complex technological problem [11].

The amount of wastewater and the pollution generated during each major operation involved in a typical leather tanning process are presented in Table $1[4,12]$. The combined volume of tannery effluent

*Corresponding author: PC Sabumon, Professor, Environmental Engineering Division, School of Mechanical and Building Sciences, VIT University, Chenna Campus, Chennai-600 127, Tamil Nadu, India, Tel: 914439931048; Fax: 914439932555; E-mail: pcsabumon@vit.ac.in/pcsabumon@gmail.com

Received January 25, 2016; Accepted March 01, 2016; Published March 08, 2016

Citation: Sabumon PC (2016) Perspectives on Biological Treatment of Tannery Effluent. Adv Recycling Waste Manag 1: 104.

DOI: 10.4172/2475-7675.1000104

Copyright: () 2016 Sabumon PC. This is an open-access article distributed under the terms of the Creative Commons Attribution License, which permits unrestricted use, distribution, and reproduction in any medium, provided the original author and source are credited. 
produced in the conventional tanning process varies from 34 to 56 $\mathrm{m}^{3} / \mathrm{T}$ (ton) of raw hide processed. This is comparable to that produced in Indian tanneries i.e., $35-40 \mathrm{~m}^{3} / \mathrm{T}$ of raw hide processed [13]. Table 2 presents the Indian and the international scenarios of characteristics of combined tannery effluents $[1,5,6,11,12,14-17]$. The characteristics of Indian tannery effluent are comparable with that produced elsewhere except in case of high TDS value. The high TDS value in Indian tannery effluent is due to addition of common salt as the major preservative for raw hides. However, the characteristic values shown in Table 2 shows that the techniques of treatment of tannery effluent employed by one country can be adopted in another country.

\section{Overview of tannery effluent treatment}

Three stages of treatment are usually required in order to meet the stringent discharge norms applicable in many countries for safe disposal of tannery effluent to the environment. They are primary, secondary and tertiary stage treatments. Such three stages of treatment are required because of the complex characteristics of tannery effluent. Primary treatment involves screening, equalization, chemical treatment and primary sedimentation. It is mainly employed to remove suspended solids, chromium, oil and grease, and sulphides in some cases. However, an appreciable amount of COD (50-65\%) and TKN (40-50\%) are also removed in the primary treatment [12].

Secondary treatment usually involves a biological process for removal of non conservative type organic matter (COD/BOD), Sulphides, and $\mathrm{TKN} / \mathrm{NH}_{4}-\mathrm{N}$ in some cases. Tertiary treatment is essential for removing refractory organic compounds imparting colour and inorganic salts and they are considered as conservative pollutants. The following sections describe tannery effluent treatment practiced in India and elsewhere.

\section{Tannery effluent treatment in developing countries}

Tanneries in developing countries like India, Bangladesh, Pakistan, Egypt, Srilanka etc. can be grouped into four major categories for effluent treatment and management [18]:

1. Large and medium scale tanneries with adequate land, finance and managerial capacity, with individual effluent treatment plants. There are nearly 200 individual tannery effluent treatment plants in India.

2. Tanneries located in clusters and do not have adequate land and financial/technical capability. Such units are usually provided with a Common Effluent Treatment Plant (CETP). There are 17 CETPs in India, out of which 13 are in Tamil Nadu, 2 in Uttar Pradesh, 1 in Bangalore and 1 in Jalandhar.

3. Cluster of tanneries in cities like Istanbul and Izmir in Turkey, Kolkata and Jalandhar in India, Colombo in Srilanka, and Cairo in Egypt etc. do not have adequate land even to set up a CETP. The only solution in such cases is to relocate and develop a separate industrial complex with CETP system. The newly established leather complex at Kolkata, India, with a CETP system to relocate all the 540 tanneries in Kolkata city is a typical example.

4. Scattered small-scale tanneries cannot set up individual effluent treatment plants. Such units should be relocated to one of the clusters with CETP system or should be closed down.

The basic process flow diagram followed in India for both individual and common effluent treatment systems, is shown in Figure $1[5,14,19]$. It can be seen from this process flow diagram that secondary stage treatment is carried out mainly for the removal of $\mathrm{BOD} /$ biodegradable COD and sulphides.

In certain cases, anaerobic process is replaced with aerobic process. A two stage aerobic treatment with an intermediate clarifier and the sludge recycling facility is usually adopted [14]. Though this approach gives a better effluent quality the cost of treatment is high.

\section{Tannery effluent treatment in developed countries}

The tannery effluent treatment in developed countries is usually carried out to a higher degree to meet the discharge standards for nitrogen also. This is because of stringent nitrogen standards are enforced in such countries. Primary treatment followed by the extended aeration process with nitrification and denitrification is practiced to obtain the required treated effluent quality. Such treatment is efficient in removal of high concentrations of suspended solids, $\mathrm{Cr}$ III, organic matter (COD/BOD), $\mathrm{TKN} / \mathrm{NH}_{4}-\mathrm{N}$ and sulphides [12]. Advanced integrated pond systems [20], Sequential Batch Reactor (SBR) technology [3,15,21-24] and MBR technology [25] are among the recently developed alternatives for the removal of both organic matter and nitrogen from tannery effluent.

\section{Appraisal of biological treatment of tannery effluent}

In Ref. [26] studied the biokinetics and toxicity assay of primary treated tannery effluents using batch reactor. Their results showed that primary treated tannery effluent is not toxic to microorganisms. Also, they concluded that a Food to Microorganism (F/M) value of 0.09 and a Hydraulic Retention Time (HRT) more than 24 hours are required for meeting the effluent BOD discharge standard of $30 \mathrm{mg} / \mathrm{L}$ applicable in India. The half-velocity constant (Ks) was in the range of 245 to 312 $\mathrm{mg} / \mathrm{L}$ as BOD. A relatively higher value of Ks for tannery wastewater as compared to that for domestic wastewater indicates that substrate removal is slower and hence, longer retention time is required for complete biodegradation of tannery wastewater. These results suggest that the extended aeration system is the most appropriate activated sludge treatment method for tannery wastewater. Ref. [27] studied the performance of a bench scale, continuous flow activated-sludge reactor for treating the primary treated effluent from a chrome-tanning industry, at temperatures varying between 12 and $34{ }^{\circ} \mathrm{C}$. They found that optimum temperature for BOD removal was between 26 and 34

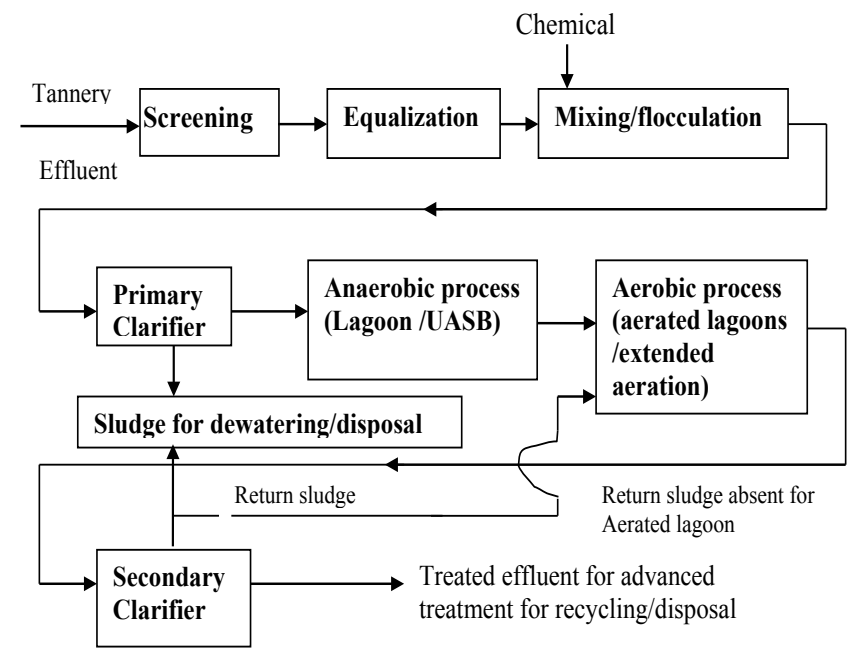

Figure 1: Process flow diagram for a typical tannery effluent treatment system in India. 


\begin{tabular}{|c|c|c|c|c|c|c|c|c|c|c|}
\hline \multirow[t]{2}{*}{ Operation/Process } & \multirow[t]{2}{*}{ WW Flow $\left(\mathbf{m}^{3} / \mathrm{T}\right)$} & \multicolumn{9}{|c|}{ Pollution load (kg/T of raw hides processed) if conventional technology is employed } \\
\hline & & S.S & COD & BOD & $\mathrm{Cr}$ & $\mathbf{S}^{2-}$ & $\mathrm{NH}_{3}-\mathrm{N}$ & TKN & $\mathrm{Cl}^{-}$ & $\mathrm{SO}_{4}^{2-}$ \\
\hline Soaking & $7-9$ & $11-17$ & $22-33$ & $7-11$ & - & - & $0.1-0.2$ & $1-2$ & $85-113$ & $1-2$ \\
\hline Liming & $9-15$ & $53-97$ & $79-122$ & $28-45$ & - & $3.9-8.7$ & $0.4-0.5$ & $6-8$ & $5-15$ & $1-2$ \\
\hline Deliming/Bating & $7-11$ & 8-12 & $13-20$ & $5-9$ & - & $0.1-0.3$ & $2.6-3.9$ & $3-5$ & $2-4$ & $10-26$ \\
\hline Tanning & $3-5$ & $5-10$ & $7-11$ & $2-4$ & $2-5$ & - & $0.6-0.9$ & $0.6-0.9$ & $40-60$ & $30-55$ \\
\hline Post Tanning & $7-13$ & $6-11$ & $24-40$ & $8-15$ & $1-2$ & - & $0.3-0.5$ & $1-2$ & $5-10$ & $10-25$ \\
\hline Finishing & $1-3$ & $0-2$ & $0-5$ & $0-2$ & - & - & - & - & - & - \\
\hline Total & $34-56$ & 83-149 & $145-231$ & $50-86$ & $3-7$ & $4-9$ & $4-6$ & $12-18$ & $137-202$ & $52-110$ \\
\hline
\end{tabular}

Table 1: Summary of pollution loads in effluents contributed by individual operations of leather tanning. SS- Suspended Solids; COD- Chemical Oxygen Demand; BODBiochemical Oxygen Demand; Cr- Chromium; $\mathrm{S}^{2}-$ Total aqueous sulphides; $\mathrm{NH}_{3}-\mathrm{N}-\mathrm{Ammonia}$ as Nitrogen; TKN- Total Kjeldhal Nitrogen; $\mathrm{Cl}^{-} \mathrm{Chloride}$; $\mathrm{SO}_{4}{ }^{2-}-\mathrm{Sulphate}$; T- Ton; WW- Wastewater (Source: European Commission [12]).

\begin{tabular}{|l|l|l|l|}
\hline S No & Characteristics & India & International $^{*}$ \\
\hline 1 & $\mathrm{pH}$ & $7-8.5$ & $7-7.5$ \\
\hline 2 & Suspended Solids & $2000-3000$ & $1844-3311$ \\
\hline 3 & $\mathrm{COD}$ & $3000-6000$ & $3222-5133$ \\
\hline 4 & $\mathrm{BOD}_{5} 20^{\circ} \mathrm{C}$ & $1200-2700$ & $1111-1911$ \\
\hline 5 & $\begin{array}{l}\text { Sulphate COD/Sulphate } \\
\text { ratio }\end{array}$ & $1000-3000 / 2-3$ & $1156-2444 / 2.1-2.8$ \\
\hline 6 & Sulphides & $25-220$ & $88-200$ \\
\hline 7 & TKN & $250-400$ & $267-400$ \\
\hline 8 & NH $-\mathrm{N}$ & $100-300$ & $89-300$ \\
\hline 9 & Chromium(III) & $60-75$ & $67-156$ \\
\hline 10 & Chloride & $6000-9500$ & $3044-5700$ \\
\hline 11 & TDS & $10000-21000$ & $8000-13899$ \\
\hline
\end{tabular}

*Calculated based on average effluent quantity of $45 \mathrm{~m}^{3} / \mathrm{T}$ of raw hide (Adapted from: European Commission).

Table 2: Characteristics of combined tannery effluent, all values are in $\mathrm{mg} / \mathrm{L}$ except $\mathrm{COD} / \mathrm{Suphate}$ ratio and $\mathrm{pH}$.

${ }^{\circ} \mathrm{C}$ and showed that primary treated effluent is amenable to biological treatment, with a BOD removal efficiency ranging from 84 to $92 \%$. Their kinetic study also yielded a higher half velocity constant (113-142 $\mathrm{mg} / \mathrm{L}$ ), indicating that activated sludge treatment of tannery effluent requires more time for the treatment. Ref. [28] demonstrated Biological pretreatment of tannery wastewater using a full-scale hydrolysis acidification system in a cold region. The average BOD/COD of the tannery wastewater was improved from 0.38 to 0.56 , and the $\mathrm{pH}$ decreased from 8.4 to 7.6 after the hydrolysis acidification treatment. The results showed that hydrolysis acidification could improve the biodegradability of the tannery effluent. Ref. [29] studied the activated sludge system for treating diluted beam house effluent. Their system achieved 99\% BOD removal efficiency at an organic loading rate lower than $2 \mathrm{~kg} \mathrm{COD} / \mathrm{m}^{3} / \mathrm{d}$, whereas COD removal was approximately $80 \%$.

The reactor operation was stable for this loading rate. For higher loading rates and $\mathrm{F} / \mathrm{M}$ ratio more than 0.15 , the system was less efficient (COD and BOD removals were lower than 40\%). These results show that high organic loading rate and $\mathrm{F} / \mathrm{M}$ ratio are not suitable for aerobic treatment of tannery effluent. Ref. [30] Studied the biological nitrogen and organic matter removal from tannery wastewater in pilot plant operations in Ethiopia by pre-denitrification and nitrification process. Ninety eight percentage removal efficiency for Total Nitrogen (TN) and $\mathrm{COD}$, and $95 \%$ removal efficiency for $\mathrm{NH}_{4}-\mathrm{N}$ were achieved in their system. Ref. [31] studied the treatment of tannery wastewater with high nitrogen content using anoxic/oxic membrane bio-reactor (MBR) and found that the reactor volume required for anoxic denitrification was only $50 \%$ of that required by a nitrification reactor. Thus, the predenitrification and nitrification process was found to be efficient for simultaneous removal of nitrogen and organic substrates from tannery wastewaters. Though this anoxic-oxic process appears to be suitable for tannery effluent, an external nitrification step and recycling of nitrate bearing effluents to anoxic zone are essential. Tannery effluent normally contains high concentration of sulphide.

The effect of sulphide on this anoxic-oxic process was not mentioned by authors. Ref. [32] described the performance of a full-scale CETP treating tannery wastewater, based on a single-sludge nitrification/ denitrification process. The monitoring was carried out for 1.5 years. Their results indicated instability and a periodic failure of nitrification/ denitrification process due to several reasons. Small deviations from the optimal $\mathrm{pH}$ in nitrification or denitrification basins, a temperature decrease to $17^{\circ} \mathrm{C}$ or an increase of the influent nitrogen content reduced the plant's efficiency from $100 \%$ to $40 \%$ during certain periods. HRT and the Sludge Retention Time (SRT) seem to be the key parameters for the process control. However, [15], in a laboratory study, showed that the SBR operation was an effective tool for the removal of COD and $\mathrm{TKN} / \mathrm{NH}_{4}-\mathrm{N}$ (partly by simultaneous nitrification-denitrification) from primary treated tannery wastewater. SBR operation is known for retaining microorganisms having less growth rate [33]. Ref. [20] studied the removal of organics and nutrients from pre-settled tannery effluent by Advanced Integrated Wastewater Pond System AIWPS. The overall organics removal performance of the AIWPS was high, with removal efficiencies in the range of $90-98 \%$ for BOD and $86-92 \%$ for COD, respectively. AIWPS reactors achieved a cumulative ammonia removal efficiency of $85 \%$. For the overloaded condition, the overall ammonia removal efficiency decreased by $50 \%$, while the BOD removal efficiency dropped by only $6 \%$, indicating the higher vulnerability of ammonia removal mechanism to high loading conditions as compared to the organic matter removal. Though pond systems are considered as low cost systems, they are discouraged for tannery effluent treatment in India because of potential odor problems. Ref. [34] Demonstrated excellent ability of the Wetland to remove the metals present in tannery wastewater. The study showed that the concentrations of trace metals $(\mathrm{Pb}, \mathrm{Zn}$ and $\mathrm{Fe})$ were reduced by $25-45 \%$, while total $\mathrm{Cr}$ was reduced by $95 \%$.

A $3.5 \mathrm{~L}$ capacity Membrane Sequential Batch Reactor (MSBR) was used for the removal of organic carbon and ammonia from wastewater coming from the beam house section of a tannery by Ref. [35]. The wastewater, produced after the oxidation of sulphide compounds, contained average COD and ammonium concentrations of 550 and $90 \mathrm{mg} / \mathrm{L}$, respectively. Removal efficiencies close to $100 \%$ in case of ammonium and $90 \%$ in case of COD were achieved. The total nitrogen removal efficiency ranged from 60 to $90 \%$. This result shows an efficient operation of membrane SBR for organic matter and ammonia removal at lower concentrations from a sulphide free tannery effluent. Ref. [36] employed an innovative biofilm-suspended biomass hybrid membrane bioreactor for tannery wastewater treatment. The growth of nitrifiers in the hybrid system was promoted in the biofilms, while heterotrophs 
were in suspension. This made it feasible to operate the unit at higher SRT for nitrifies than that for heterotrophs. During the treatment of the tannery wastewater, organic loading rate (OLR) and ammonia loading rate (ALR) were increased stepwise up to $4.5 \mathrm{~kg} \mathrm{COD} / \mathrm{m}^{3} / \mathrm{d}$ and $1.2 \mathrm{~kg} \mathrm{NH} \mathrm{NH}_{4} \mathrm{~N} / \mathrm{m}^{3} / \mathrm{d}$, respectively. COD removal efficiency was $95 \%$, while ammonia removal efficiency was $97 \%$. The concentration of ammonia in the effluent was as low as $10 \mathrm{mg} \mathrm{NH}_{4}-\mathrm{N} / \mathrm{L}$. Moreover, the membrane filtration unit made it feasible to operate the reactor at high OLR, without affecting either the settling properties of the sludge or the nitrogen conversion efficiency. Though this process is promising, costs of membrane treatment and maintenance are prohibitive at present scenario. Therefore membrane treatments may not be an attractive option for developing countries. Ref. [11] reported the results of an investigation on combining the biological degradation (sequential batch biofilm reactor (SBBR)) with chemical oxidation by ozone. The combined treatment was carried out in a laboratory scale reactor using the primary effluent from a centralized plant treating the wastewater from a large tanning district in Northern Italy. SBBR performance with ozonation was satisfactory with average $\mathrm{COD}, \mathrm{NH}_{4}-\mathrm{N}$ and TSS removal efficiencies of $97 \%, 98 \%$ and $99.9 \%$, respectively. Compared to suspended growth systems, the main advantages of biofilm systems are:

(a) greater biomass concentration in the reactor with corresponding higher specific removal rates,

(b) greater volumetric loads,

(c) increased process stability towards shock loadings and

(d) biomass enrichment of slow growing organisms such as nitrifies.

Ref. [14] assessed the quality of treatment of tannery wastewater in India in two CETPs, constructed for two tannery clusters, at Jajmau (Kanpur) and at Unnao in the state of Uttar Pradesh, India. The Jajmau plant employs an upflow anaerobic sludge blanket (UASB) process, while the Unnao plant employs two stage activated sludge process (ASP). Investigations indicated that the performance of the ASP was superior. The treated effluent from the UASB had higher BOD/ COD and considerable amounts of chromium (Cr) and sulphide, as compared to that in the effluent from the ASP. The reason for less amount of chromium in ASP was the prior removal of chromium in primary treatment, whereas there was no prior removal of chromium in the UASB based plant. The results of this study did not agree with the conventional wisdom that anaerobic processes are superior in tropical countries like India for treatment of tannery effluents. The major reason for this could be the sulphide inhibition while treating tannery effluent having low $\mathrm{COD} / \mathrm{SO}_{4}{ }^{2-}$ ratio. From Table 1 , it is evident that tannery effluent is having lower $\mathrm{COD} / \mathrm{SO}_{4}^{2-}$ ratio. This ratio becomes lower than
1.5 after primary treatment, as there is removal of COD in primary treatment excluding $\mathrm{SO}_{4}{ }^{2-}$ removal. At $\mathrm{COD} / \mathrm{SO}_{4}{ }^{2-}$ ratios lower than 10 ; anaerobic process failures are reported due to sulphide inhibition [37].

An Up flow Anaerobic Fixed Biofilm Reactor (UAFBR) has been developed to treat tannery wastewater by Ref. [38]. Effects of major process variables such as HRT, Organic Loading Rate (OLR), and temperature on the COD removal in the reactor were evaluated. This technology ensures the retention of the active methanogenic biomass within the reactor, independent of the HRT. COD removal efficiency (60-75\%) remained stable for a wide range of organic loading rates and operating temperatures. Their results showed that fixed biofilm reactor is a promising alternative to the anaerobic treatment of tannery effluents. However, the author has not addressed the sulphide toxicity with details of $\mathrm{COD} / \mathrm{SO}_{4}{ }^{2-}$ ratio. Table 3 summarizes the performances of various technologies for anaerobic treatment of tannery effluents. It can be seen from this Table that adoption of sulphide inhibition control [39] results in better treatment efficiency at lower HRT. It can also be observed that the treatment performance improves with HRT and biomass retention inside the reactors. However, the maximum treatment performance achieved by direct anaerobic treatment is lower as compared to that in extended aeration process. This is because of sulphide toxicity developed in anaerobic process while treating high sulphate containing tannery effluent. A separate section 4 is provided to deal with anaerobic treatment of sulphate bearing effluent in this paper. Ref. [40] studied biological sulfate removal from tannery wastewater in a two-stage pilot scale anaerobic treatment system. The concentration of sulfate in the influent had a significant effect on the sulphate reduction in both the stages. The removal efficiency of sulfate in the first stage was approximately $30 \%$. In the second stage, sulphate reduction decreased with higher concentrations of sulfate in the influent. Ref. [6] studied the feasibility of using tannery effluent as organic carbon source for sulphate reduction process to produce sulphide, which has the potential for metal precipitation. Such an approach can be employed for acid mine drainage treatment. In their reactor, sulphate reduction varied from $60-80 \%$ for a feed sulphate concentration of $1800 \mathrm{mg} / \mathrm{L}$.

It can be seen from the appraisal of biological treatment of tannery effluent that the aerobic treatment of tannery effluent is superior to anaerobic treatment. However, the aerobic treatment requires extended aeration time for satisfactory removal of COD/BOD. Anaerobic treatment of tannery effluent performs well when sulphide produced in the process is properly controlled. SBR and/or MBR technology appear to be suitable for combined removal of organic carbon and nitrogen. However, they require sulphide removal as a pretreatment to obtain

\begin{tabular}{|c|c|c|c|c|c|c|}
\hline Author & Substrate & Treatment & $\begin{array}{l}\text { HRT, } \\
\text { days }\end{array}$ & $\begin{array}{l}\text { Influent COD, } \\
\mathrm{mg} / \mathrm{L}\end{array}$ & $\begin{array}{l}\text { Volumetric loading } \\
\text { rate, } \mathrm{Kg} \mathrm{COD} / \mathrm{m}^{3} / \mathrm{d}\end{array}$ & $\begin{array}{l}\text { \% COD } \\
\text { Removal }\end{array}$ \\
\hline \multirow{2}{*}{ [39] } & \multirow{2}{*}{ Beam house } & $\begin{array}{c}\text { Fixed bed reactor- } 1 \text { with sulphide inhibition control }(30 \mathrm{mg} / \mathrm{L} \\
\mathrm{H}_{2} \mathrm{~S} \text { ) by external biogas stripping and cleaning }\end{array}$ & 1.9 & 6100 & 3.2 & 80 \\
\hline & & $\begin{array}{l}\text { Fixed bed reactor - } 2 \text { without sulphide inhibition control (140 } \\
\qquad \mathrm{mg} / \mathrm{L} \mathrm{H}_{2} \mathrm{~S} \text { ) }\end{array}$ & 2.1 & 6100 & 2.9 & 58 \\
\hline [40] & Wastewater & Fixed film & 4.6 & 5250 & 1.14 & 66.1 \\
\hline [46] & Wastewater & Fixed bed & 2.44 & 4440 & 1.82 & 66.2 \\
\hline \multirow{3}{*}{ [50] } & \multirow{3}{*}{ wastewater } & \multirow{3}{*}{ Stirred reactor } & 15 & 4163 & 0.28 & 36.4 \\
\hline & & & 25 & 4074 & 0.16 & 59.6 \\
\hline & & & 30 & 4074 & 0.14 & 60.3 \\
\hline [39] & Beamhouse & Contact process & 2.5 & $2000-15000$ & $1.27-3.89$ & 62 \\
\hline \multirow{2}{*}{ [40] } & \multirow{2}{*}{ Beamhouse } & Fixed bed reactor & 1 & 3000 & 3 & 51 \\
\hline & & Fixed bed reactor with circulation & 1 & 3000 & 3 & 39 \\
\hline
\end{tabular}

Table 3: Anaerobic treatment of tannery wastewater (Adapted from Weimann et al. [39]). 
improved performance. Also an extended period of aeration is required for nitrification. The above limitation of developed processes calls for an effective alternate treatment of tannery effluent.

Following sections discuss relevant literature related to anaerobic treatment of sulphate bearing effluents and recent developments in biological oxidation of ammonia and denitrification processes for nitrogen removal from wastewaters. The knowledge in these sections will be helpful in possibilities of developing an alternate effective effluent treatment system for tannery effluent and other similar kind of wastewaters.

\section{Anaerobic treatment of sulphate bearing effluents}

Sulphates bearing waste streams are generated by many industrial processes such as tannery, food processing (e.g., molasses, sea food, edible oil, etc.), pharmaceutical, pulp and paper, and petrochemical [39-41]. Under anaerobic conditions, sulphate can act as an electron acceptor for a group of bacteria that can couple the oxidation of reduced organic or inorganic compounds to the reduction of sulphate for bioenergetic purposes. This process is known as dissimilatory sulphate reduction (Sulphidogenesis) and the bacteria involved are known as the sulphate reducers or sulphate- reducing bacteria $[42,43]$. Based on the metabolic capacities, sulphate reducing bacteria can be classified into two categories - those species or genera that are capable of complete oxidation of organic compounds to $\mathrm{CO}_{2}$ and those that carry out incomplete oxidation, usually to acetate as end-product [42]. The majority of sulphate-reducing bacterial species can also utilize sulphite, thiosulphate, organic sulphur compounds and elemental sulphur as electron acceptors $[44,45]$.

Anaerobic treatment of sulphate bearing wastewater imposes severe toxicity to methane producing bacteria (MPB) because of the generation of high levels of sulphide in the process [46-49] and/ or by direct sulphide load [39] along with the effluent. Toxicity of sulphide is $\mathrm{pH}$ dependent since only the unionized hydrogen sulphide can pass through the cell membrane and therefore, free $\mathrm{H}_{2} \mathrm{~S}$ is more toxic compared to other sulphide species [50,51]. Hydrogen sulphide dissociates in water according to the following equations [52]:

$$
\begin{aligned}
& \mathrm{H}_{2} \mathrm{~S} \leftrightarrow \mathrm{H}^{+}+\mathrm{HS}^{-} ;\left(\mathrm{K}_{1}=1.0 \times 10^{-7}\right) \\
& \mathrm{HS}^{-} \leftrightarrow \mathrm{H}^{+}+\mathrm{S}^{2-} ;\left(\mathrm{K}_{2}=1.0 \times 10^{-14}\right)
\end{aligned}
$$

Virtually all dissolved sulphide is present in the ionised form when $\mathrm{pH}$ is more than 8-9. At neutral $\mathrm{pH}$ values, typical of methanogenic systems, approximately $20-50 \%$ of the dissolved sulphide is present in the undissociated $\mathrm{H}_{2} \mathrm{~S}$ form. Much of the published literature on sulphide toxicity does not take $\mathrm{pH}$ and bacterial adaptation into consideration, which makes general conclusions about toxicity levels difficult. Literature on $\mathrm{H}_{2} \mathrm{~S}$ inhibition of methanogenesis is inconclusive (Table 4). Ref. [51] summarizes a few of the reported data, from which it can be concluded that total dissolved sulphide in the range of 150$1100 \mathrm{mg} / \mathrm{L}$ and free hydrogen sulphide in the range of 50-250 mg/L can cause inhibitory effects. Also, the sulphide inhibition depends on the type of substrate [53] and has different degrees of effect on various bacterial groups [54]. Ref. [47,55] have found that sulphide toxicity is experienced at lower concentrations in suspended growth systems as compared to that in anaerobic filters. In general, it was found that the sulphide inhibition often leads to a complete process failure since methanogenesis is crucial for anaerobic organic stabilization $[46,56]$.

Sulphide also precipitates all essential trace metals required for methanogens as metallic sulphides. The other most obvious effect on methanogenesis is a reduction of the methane yield per unit COD converted. In terms of sulphate, the reduction of $1.5 \mathrm{~g} \mathrm{SO}_{4}^{2-}$ requires oxidation of $1 \mathrm{~g}$ COD, resulting in a decrease of $0.233 \mathrm{~m}^{3}$ in the methane (STP) yield for every $\mathrm{kg}$ of $\mathrm{SO}_{4}^{2-}$ reduced during anaerobic treatment [57].

Other problems associated with anaerobic treatment of high sulphate bearing wastewaters result from the presence of sulphide in the biogas and in the effluent. Hydrogen sulphide, even at concentrations $\leq 2 \mathrm{ppm}$ causes malodor. Though burning of $\mathrm{H}_{2} \mathrm{~S}$-containing biogas is feasible, it produces acidic gases. The presence of $\mathrm{H}_{2} \mathrm{~S}$ in biogas may also cause severe problems of corrosion, necessitating costly sulphide stripping techniques. The presence of dissolved sulphide in the effluent after anaerobic treatment also gives rise to malodor and enhanced oxygen demand. Post-treatment of the effluent may be necessary, depending on the sulphide concentration, and is generally accomplished either by chemical precipitation with iron salts or biological or chemical oxidation [50].

Available information on the sensitivity of sulphate reducing bacteria (SRB) to sulphide toxicity is also inconclusive. In general, methanogens are known to be more sensitive compared to SRBs [58]. Ref. [59] concluded that SRBs were not affected by high concentrations of hydrogen sulphide. However, Ref. [42] reported inhibition of Desulfotomaculum acetooxidans at hydrogen sulphide concentrations more than $85 \mathrm{mg} / \mathrm{L}$. Ref. [60] indicated that SRBs are more sensitive to elevated levels of dissolved total sulphide than Methane Producing Bacteria (MPB).

\section{Competition between sulphate reducers and other bacteria involved in anaerobic mineralization}

Figure 2 illustrates the possible anaerobic pathways of organic compound degradation under methanogenic and sulphidogenic conditions. In the presence of sulphate, competition between sulphate reducers and the anaerobic bacteria involved in methanogens [61] can occur at different levels in the stepwise degradation process as listed below:

1. Competition between sulphate reducers and fermentative bacteria for monomeric compounds, such as sugars, amino acids, etc.

2. Competition between sulphate reducers and Obligate Hydrogen Producing Acetogens (OHPA) for intermediate fermentation products, such as propionate, butyrate, ethanol, etc.

\begin{tabular}{|l|l|l|l|l|l|l|}
\hline Biomass & Substrate & DS & FS & Inhibition & T & pH \\
\hline Suspended & DW & 390 & 130 & $50 \%$ & 37 & $7.0-7.2$ \\
\hline Suspended & Acetate & 295 & 125 & $50 \%$ & 35 & $6.5-7.4$ \\
\hline Suspended & Acetate & 1060 & 100 & $50 \%$ & 35 & $7.7-7.9$ \\
\hline Suspended & Lactate & 250 & 100 & $50 \%$ & 35 & 7.0 \\
\hline Suspended & Lactate & 1630 & 100 & $50 \%$ & 35 & 8.0 \\
\hline Suspended & $\mathrm{C}_{2}, \mathrm{C}_{3}$ & $145-195$ & $60-65$ & $*$ & 35 & $7-0-7.2$ \\
\hline Suspended & $\mathrm{C}_{2}, \mathrm{C}_{3}$ & $150-200$ & $60-75$ & $*$ & 35 & 7.0 \\
\hline Biofilm & Propionate & 1000 & 200 & $*$ & 35 & 7.4 \\
\hline Biofilm & Acetate & 400 & 125 & NR & 35 & 7.2 \\
\hline Granular & Acetate & 676 & 250 & $50 \%$ & 30 & $6.4-7.2$ \\
\hline Granular & Acetate & 1045 & 90 & $50 \%$ & 30 & $7.8-8.0$ \\
\hline Tin ${ }^{\circ} \mathrm{C}, \mathrm{Dis}$ & Sulphide & DS) & & & & \\
\hline
\end{tabular}

$\mathrm{T}$ in ${ }^{\circ} \mathrm{C}$, Dissolved Sulphide (DS) and Free hydrogen Sulphide (FS) in $\mathrm{mg} \mathrm{S} / \mathrm{L}$ NR-Not reported, DW- distillery wastewater, $\mathrm{C}_{2}$-acetate, $\mathrm{C}_{3}$-propionate. *Process failure, "Inhibition threshold for adapted sludges.

Table 4: Sulphide toxicity in methanogenic process (Adapted from Karhadkar et al. [103], McCartney and Oleskiewicz [48], Parkin et al. [46], Maillacheruvu et al. [47]). 


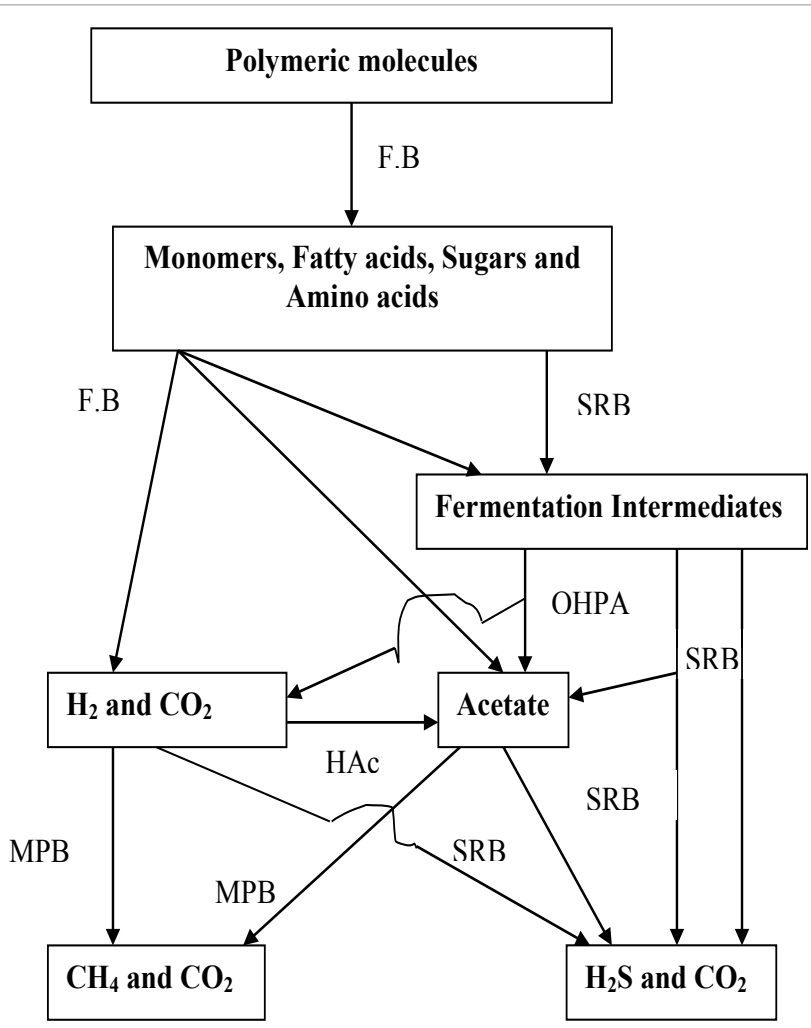

F.B-Fermentative bacteria; SRB-Sulphate reducing bacteria; OHPA-Obligate hydrogen producing acetogenic bacteria; HAc-Homo Acetogens; MPB-Methane producing bacteria

Figure 2: Pathways of organic compound degradation under methanogenic and sulphidogenic conditions.

3. Competition between sulphate reducers and homoacetogenic bacteria for $\mathrm{H}_{2}$.

4. Competition between sulphate reducers and methanogens for direct methanogenic substrates, such as $\mathrm{H}_{2}$ and acetate.

Competition between sulphate reducers and fermentative bacteria: Usually sulphate reducers do not effectively compete with the fast-growing fermentative bacteria involved in polymer hydrolysis and monomer degradation in anaerobic environments [42,62]. However, there is evidence of malate and fumarate fermented by a number of SRB species irrespective of the $\mathrm{H}_{2}$ partial pressure $[42,44]$ and fermentation of some other substrates, such as ethanol, lactate, glycerol, propionate, etc., only if the $\mathrm{H}_{2}$ partial pressure is maintained at a low level $[42,62]$. It is likely that, in natural ecosystems and in anaerobic digesters, sulphate reducers are more likely to be involved in the ultimate and penultimate stages of mineralization than in the initial fermentative stage [63].

Competition between sulphate reducers and OHPA bacteria: Several researchers have reported that SRB can compete with OHPA bacteria for substrates such as butyrate [42,64] and propionate $[46,65]$. Complete or partial sulphidogenic oxidation of fermentation intermediates is favored over the OHPA syntrophic route due to the insensitivity of the former to hydrogen partial pressures, thermodynamic and kinetic parameters $[42,62,66]$. In marine sediments, between 75 to $99 \%$ of organic substrate electrons appear to be scavenged by SRB species [59].
Competition between sulphate reducers and homoacetogenic bacteria: Ref. [61] reported that from thermodynamic and substrate affinity considerations, $\mathrm{H}_{2}$ oxidizing sulphate reducers should effectively out-compete homoacetogens under the conditions prevailing in digesters.

Competition between sulphate reducers and methanogens: In natural environments and in anaerobic reactors, hydrogen and acetate are the key intermediates through which organic matter is channeled during both methanogenic and sulphidogenic mineralization [42]. Thermodynamic considerations are often used to predict the outcome of competition between SRB and MPB species for both the substrates $[42,48,61]$. As presented in Table $5, \Delta \mathrm{G}^{\circ}$ values predict that sulphate reducers could out-compete methanogens for both $\mathrm{H}_{2}$ and acetate.

SRB species have a higher affinity for hydrogen than methanogens (Table 5) and this higher affinity, coupled with yield coefficient data, suggest that SRB should effectively out-compete MPB under normal digester operating conditions and at limiting substrate levels $[42,48]$. Ref. [67] proposed that SRB have a higher affinity for hydrogen than MPB. This is because the hydrogenase enzyme is located in the periplasmic space in the former and it is located in the cytoplasm in the latter. SRB could reduce sulphate with $\mathrm{H}_{2}$ as substrate even at HRT of 2 hours in an acidogenic chemostat [58]. Kinetic data (Table 5) also suggest that SRB could successfully out-compete Methanosarcina Sp. at low acetate concentrations prevailing in natural environments and anaerobic reactors. Given the very low levels of $\mathrm{H}_{2}$ and acetate that may prevail in natural environments and in steady state anaerobic digesters, a comparison of minimum substrate threshold values may be a more useful guide for prediction of the outcome of competition between SRB and MPB species [61]. Ref. [68] determined threshold concentrations for $\mathrm{H}_{2}$ for a variety of anaerobes and concluded that there was an inverse correlation between the free energy available for the reaction and the threshold value. Threshold values for $\mathrm{H}_{2}$ for sulphate reducers were found to be lower than those for methanogens (Table 5), indicating that SRB species can lower the $\mathrm{H}_{2}$ partial pressure to a lower level such that it cannot be utilized by hydrogenophilic methanogens. Similarly, threshold values of acetate for sulphate reducers were lower than methanogens making SRBs more competitive at lower acetate concentrations. In the study conducted by Ref. [69], SRB out-competed methanogens in the acetate-fed chemostats because sulfate reducers have lower half-velocity constant (Ks) than methanogens for acetateutilization.

From the above discussion, it is seen that SRB have an advantage over MPB in utilizing the common substrates. The $\mathrm{COD} / \mathrm{SO}_{4}^{2-}$ ratio appears to be a key factor in the regulation of the competition between methanogenic and sulphate-reducing bacteria $[40,48,64]$. A common recommendation for a successful anaerobic treatment of wastewater is to operate the system at $\mathrm{COD} / \mathrm{SO}_{4}{ }^{2-}$ ratio higher than 10 [50]. For such wastewaters, the $\mathrm{H}_{2} \mathrm{~S}$ concentration in the anaerobic reactor will never exceed the critical value of inhibition due to the stripping effect of the biogas produced. At COD/sulfate ratios lower than 10, process failures of anaerobic reactors have been reported [37,46] and the process

\begin{tabular}{|l|l|l|l|}
\hline Biochemical Reaction & $\begin{array}{l}\Delta \mathbf{G}^{\circ}(\mathrm{KJ} / \\
\text { Reaction })\end{array}$ & $\begin{array}{l}\text { Apparent } \\
\mathbf{K m}(\boldsymbol{\mu M})\end{array}$ & $\begin{array}{l}\text { Minimum } \\
\text { threshold (nM) }\end{array}$ \\
\hline $4 \mathrm{H}_{2}+\mathrm{CO}_{2} \longrightarrow \mathrm{CH}_{4}+2 \mathrm{H}_{2} \mathrm{O}$ & -135 & $5-13$ & $23-75$ \\
\hline $4 \mathrm{H}_{2}+\mathrm{HSO}_{4}^{-} \rightarrow \mathrm{HS}^{-}+4 \mathrm{H}_{2} \mathrm{O}$ & -152 & 2 & 7 \\
\hline $\mathrm{CH}_{3} \mathrm{COO}^{-}+\mathrm{H}_{2} \mathrm{O} \longrightarrow \mathrm{CH}_{4}+\mathrm{HCO}_{3}^{-}$ & -31 & $(3-5) 10^{3}$ & $(0.5-1.2) 10^{6}$ \\
\hline $\mathrm{CH}_{3} \mathrm{COO}^{-}+\mathrm{SO}_{4}^{2-} \rightarrow \mathrm{HS}^{-}+2 \mathrm{HCO}_{3}^{-}$ & -47 & $0.2 \times 10^{3}$ & $1 \times 10^{3}$ \\
\hline
\end{tabular}

Table 5: Free energy, apparent $\mathrm{Km}$ and minimum substrate threshold values for hydrogenophilic and acetoclastic methanogens and sulphate reducers (Source: Widdel [42], Cord-Ruwisch et al. [68], Zinder [61]). 
proceeds successfully when precautions are taken to prevent sulphide toxicity. Addition of ferric salts to precipitate sulphides, dilution of the influent $\mathrm{H}_{2} \mathrm{~S}$ concentration, decrease of unionized $\mathrm{H}_{2} \mathrm{~S}$ concentration at elevated $\mathrm{pH}$, separation of $\mathrm{H}_{2} \mathrm{~S}$ production and methanogenesis, selective inhibition of SRB, aerobic biological sulphide oxidation to elemental sulphur, and recycling of effluent containing low sulphide concentration to anaerobic process, Oxidation-Reduction Potential (ORP) based oxygenation for sulphide control by injecting controlled oxygen to biogas recycling line, are some of the sulphide inhibition control measures $[37,70-73]$. So far, no sustainable method has been developed for selective inhibition of SRB to drive the anaerobic process towards methanogens [37]. Also, many of the developed sulphide inhibition methods are not economically feasible or sustainable. For example, separation of $\mathrm{H}_{2} \mathrm{~S}$ production and methanogenesis may be costly because it requires an additional reactor and accessories, which increases the complexity of treatment system [73].

\section{Anaerobic digestion of low $\mathrm{COD} / \mathrm{SO}_{4}{ }^{2-}$ ratio bearing industrial wastewaters}

Ref. [74] used a laboratory-scale UASB reactor in which $5 \mathrm{mg} / \mathrm{L}$ chloroform was added for 5 days to terminate methanogenesis and then fed it with an influent containing 2,500 $\mathrm{mg} / \mathrm{L} \mathrm{COD} \mathrm{and} \mathrm{5,000} \mathrm{mg} / \mathrm{L} \mathrm{SO}_{4}{ }^{2-}$ for a 180 day trial period. No methane production was detected from this 'sulphidogenic' reactor throughout the experiment and, towards the end of the trial; a COD conversion rate of 0.9-1.0 g COD $/ \mathrm{gVSS} / \mathrm{d}$ was achieved. In a parallel 'sulphidogenic/methanogenic' (i.e., mixed) reactor which had not been treated with chloroform, the percentage of organic COD used by SRB in similar feeding conditions was about $50 \%$ at the start of the experiment and gradually increased to $80 \%$ over the first 150 days of feeding. This was correlated with an increase in the proportion of acetate being used for sulphate reduction. Ref. [75] were the first to demonstrate the feasibility of treating industrial wastewaters which contain a very low $\mathrm{COD} / \mathrm{SO}_{4}{ }^{2-}$ ratio in sulphidogenic reactors in which methanogenesis is completely suppressed. Ref. [20] conducted a pilot scale experiment using advanced facultative pond system to study the competition between SRB and Methanogenic Archaea (MA) in anaerobic treatment of tannery wastewater. The relative electron flow towards sulphate reduction was higher (59-83\%) than that towards methanogenesis (41-17\%), although the COD removal within the reactor varied from 15 to $90 \%$. Results from this study also demonstrated that the flow of electrons towards SRB increased with an increase in sulphate concentration and a decrease in $\mathrm{COD} / \mathrm{SO}_{4}{ }^{2-}$ ratio.

\section{Overview of biological nitrogen removal process}

Discharge of untreated wastewater containing nitrogen compounds (TKN, $\mathrm{NH}_{4}-\mathrm{N}$, oxidized nitrogen compounds) is responsible for promoting eutrophication in receiving water and adversely affects the human health and aquatic life [76,77]. As nitrogen pollution has become a cause for concern in recent times, many countries are enforcing stringent nitrogen discharge standards. As a result, development of techniques for reducing the nitrogen content from wastewaters has attracted a great deal of attention [78].

Conventional wastewater treatment systems for nitrogen removal are based on both aerobic nitrification and anaerobic or anoxic denitrification $[79,80]$. This combination requires the spatial separation of nitrification and denitrification units or temporal separation of each process by alternating aeration and no aeration in the same unit. The process involves two stages:

(1) conversion of ammonium into nitrate (nitrification); and

(i1) subsequent transformation of nitrate into nitrogen gas (denitrification).
Nitrifiers, such as Nitrosomonas and Nitrobacter, oxidize $\mathrm{NH}_{4}-\mathrm{N}$ to nitrite and nitrate using free oxygen [81] as per equations 3 and 4 . Then, denitrifiers oxidize organic carbon using nitrate as the electron acceptor under anoxic conditions as per equation 5 [77]. Though conventional nitrification followed by denitrification (with external organic carbon supply) can be carried out as separate processes, combining anoxic and aerobic units with nitrate recycling has been commonly used for nitrogen removal in full-scale wastewater treatment plants [82]. This process may remove up to $80 \%$ of the $\mathrm{NO}_{3}-\mathrm{N}$ when a $400 \%$ recycling rate is used $[83,84]$.

$$
\begin{aligned}
& \mathrm{NH}_{4}^{+}+1.5 \mathrm{O}_{2} \stackrel{\text { Nitrosomanas }}{\longrightarrow} \mathrm{NO}_{2}^{-}+2 \mathrm{H}^{+}+\mathrm{H}_{2} \mathrm{O} ; \Delta \mathrm{G}^{0}=-275 \mathrm{KJ} / \mathrm{M} \\
& \mathrm{NO}_{2}{ }^{-}+0.5 \mathrm{O}_{2} \stackrel{\text { Nitrobactor }}{\longrightarrow} \mathrm{NO}_{3}{ }^{-} ; \Delta \mathrm{G}^{\circ}=-74 \mathrm{KJ} / \mathrm{M} \\
& 1.25 \mathrm{CH}_{3} \mathrm{COOH}+2 \mathrm{NO}_{3}^{-} \frac{\text { Deninificans }}{\text { Hetertrontic }} \longrightarrow \mathrm{N}_{2}+2.5 \mathrm{CO}_{2}+1.5 \mathrm{H}_{2} \mathrm{O}+2 \mathrm{OH}^{-} \Delta \mathrm{G}^{\circ}=-527.4 \mathrm{KJ} / \mathrm{M}
\end{aligned}
$$

Conventional nitrification can be implemented only after pretreating the wastewater to reduce the $\mathrm{C} / \mathrm{N}$ ratio [85]. In conventional suspended growth biological nitrogen removal system, it is difficult to maintain sufficient nitrifying biomass because of the low growth rate of nitrifying bacteria $[86,87]$. During biological denitrification of wastewater, external organic carbon is needed as the electron donor for the reduction of nitrate and nitrite to nitrogen gas. The COD/N ratio required for complete denitrification may range from 3.5 to 15 g COD /g N [88]. Biological nitrogen removal can also be achieved by nitrification and denitrification under alternating aerobic-anoxic conditions in the same reactor. A few advantages that can be accrued by a single sludge system over conventional ones are:

i) No prior carbon removal step required before nitrification,

ii) No external carbon source is needed for denitrification,

iii) Lesser buffer quantity is needed as alkalinity generated during denitrification can partly compensate for the alkalinity destroyed in nitrification [89].

For wastewater with a low $\mathrm{BOD} / \mathrm{N}$ ratio, autotrophic denitrification is a promising alternative to heterotrophic denitrification [90]. Autotrophic denitrifying bacteria include autohydrogenotrophic denitrifiers [91] as well as autosulphurotrophic denitrifiers, which oxidize reduced sulphur compounds (sulphides, elemental sulphur and thiosulphate) to sulphate while reducing nitrate to $\mathrm{N}_{2}$ gas. Contrary to heterotrophic denitrification, autotrophic denitrification eliminates the need for addition of organic carbon sources, consumes alkalinity and generates high concentrations of sulphate [90]. So in anoxic conditions, the tannery effluent contained nitrates could be denitrified by both heterotrophic and autotrophic route effectively.

ANAMMOX is the acronym for anaerobic ammonia oxidation. The ANAMMOX process is the denitrification of nitrite with ammonia as the electron donor. ANAMMOX needs a preceding partial nitrification step that converts half of the wastewater ammonium to nitrite. On laboratory scale, ANAMMOX has been tested in different reactors: fluidized bed [92], fixed bed [93], sequential batch [33] and gas-lift reactors [94]. All the above reactors appeared to be suitable, although the economics of the process differs for different reactor configurations. The temperature range for ANAMMOX is $20-43^{\circ} \mathrm{C}$ with an optimum value at $40^{\circ} \mathrm{C}$. The ANAMMOX system performed well in the $\mathrm{pH}$ range of 6.7- 8.3. One of the main problems of the ANAMMOX process is the long start-up time. For example, the ANAMMOX planctomycetes grow slowly and it takes about 100 to 150 days for an ANAMMOX reactor inoculated with activated sludge to reach its full capacity [95]. It has also been reported that presence of organic matter (OM) adversely 
affects ANAMMOX [96,97] and co-existence of ANAMMOX culture and denitrifiers during start-up could slow down anaerobic ammonia removal [98].

So far $\mathrm{NO}_{2}{ }^{-}, \mathrm{NO}_{3}{ }_{3}^{-}$and $\mathrm{SO}_{4}{ }^{2-}$ have been reported as electron acceptors for anoxic ammonia oxidation as per the reactions given in Eqs. (6) to (8) $[33,78,99]$.

$$
\begin{aligned}
& 5 \mathrm{NH}_{4}^{+}+3 \mathrm{NO}_{3}^{-} \rightarrow 4 \mathrm{~N}_{2}+9 \mathrm{H}_{2} \mathrm{O}+2 \mathrm{H}^{+} ; \Delta \mathrm{G}^{\mathrm{o}}=-297 \mathrm{KJ} / \mathrm{M} \\
& \mathrm{NH}_{4}^{+}+\mathrm{NO}_{2}^{-} \rightarrow \mathrm{N}_{2}+2 \mathrm{H}_{2} \mathrm{O} ; \Delta \mathrm{G}^{\circ}=-357 \mathrm{KJ} / \mathrm{M} \\
& \mathrm{NH}_{4}^{+}+1.31 \mathrm{NO}_{2}^{-}+0.066 \mathrm{HCO}_{3}^{-}+0.13 \mathrm{H}^{+} \rightarrow \mathrm{N}_{2}+0.26 \mathrm{NO}_{3}^{-} \\
& +0.066 \mathrm{CH}_{2} \mathrm{O}_{0.5} \mathrm{~N}_{0.15}+2 \mathrm{H}_{2} \mathrm{O} \\
& 2 \mathrm{NH}_{4}^{+}+\mathrm{SO}_{4}^{2-} \rightarrow \mathrm{S}_{+}+\mathrm{N}_{2}+4 \mathrm{H}_{2} \mathrm{O} ; \Delta \mathrm{G}^{\circ}=-48 \mathrm{KJ} / \mathrm{M}
\end{aligned}
$$

Equation 8 shows the feasibility of anoxic oxidation of ammonia in presence of sulphate. Recently, Ref. [100] observed ammonia removal associated with sulphate reduction. Also, Ref. [101-103] developed a viable process for simultaneous removals of COD/BOD, $\mathrm{NH}_{4}-\mathrm{N}$ and sulphide /sulphate with possibility of sulphur recovery for the treatment of tannery effluent. The major processes involved were sulphate reduction, sulphide oxidation, nitrification, ANAMMOX and/or denitrification. The sulphide inhibition control in this process was achieved by controlled air injection to the part of reactor. This air injection could oxidize part of ammonia to nitrite/nitrate and denitrification was effective in presence of reduced organic compounds and sulphides. Such integrated treatment system has the advantages of high loading rates with a mixed consortium of bacteria. More focused research is required for development of such mixed bacterial consortium with involvement of multiple electron donors and electron acceptors for simultaneous removal of multiple pollutants present in many wastewaters. The major advantages of such integrated treatment systems are less reactor volume demand because of higher loading rates obtained.

\section{Conclusions}

Primary treated tannery effluent after chromium removal is found to be suitable for secondary stage biological treatment. The inherent nature of tannery effluent demands more aeration time and lesser organic loading rates for efficient aerobic treatment. Lower COD/ $\mathrm{SO}_{4}^{2-}$ ratio of tannery effluent is an impediment in successful anaerobic treatment. Sulphide inhibition control is essential for an effective anaerobic treatment of tannery effluent with high cost of treatment with less biogas recovery. Sequencing Batch Reactor (SBR) and membrane reactor technologies are found to be satisfactory for removal of organic matter and ammonia. However, the operational cost of such technologies is high and may not be attractive to developing countries. The use of abundantly available $\mathrm{SO}_{4}{ }^{2-}$ as an alternate electron acceptor for organic matter removal and anoxic ammonia oxidation is worth considering. It is possible to treat tannery effluent by an alternate sulphidogenesis process with proper design and operational control. Such treatment enables simultaneous removals of COD/BOD, $\mathrm{NH}_{4}-\mathrm{N}$ and sulphide/sulphate with possibility of elemental sulphur recovery at higher loading rates.

\section{References}

1. Rao JR, Chandrababu NK, Muralidharan C, Nair BU, Rao PG, et al. (2003) Recouping the wastewater: a way forward for cleaner leather processing. Journal of Cleaner Production 11: 591-599.

2. Kennedy $L$ (1999) Co-operating for survival: Tannery pollution and joint action in the Palar valley, India. World Development 27: 1673-1691.
3. Lefebvre O, Vasudevan N, Torrijos M, Thanasekaran K, Moletta R (2005) Halophilic biological treatment of tannery soak liquor in a sequencing batch reactor. Water Research 39: 1471-1480.

4. UNIDO (2000) Pollutants in tannery effluents, Regional Programme for Pollution Control in the Tanning Industry in South-East Asia, The Scope for Decreasing Pollution Load in Leather Processing.

5. Kaul SN, Tapas N, Vyas RD, Szpyrkowicz L (2001) Waste management in tanneries: Experience and outlook. Journal of Indian Association of Environmental Management 28: 56-76.

6. Boshoff G, Duncan J, Rose PD (2004) Tannery effluent as a carbon source for biological sulphate reduction. Water Research, 38: 2651-2658.

7. Kongjao S, Damronglerd S, Hunsom M (2008) Simultaneous removal of organic and inorganic pollutants in tannery wastewater using electro coagulation technique. Korean Journal of Chemical Engineering 25: 703-709.

8. Kolomaznik K, Adamek M, Andel I, Uhlirova M (2008) Leather waste potential threat to human health and a new technology of its treatment. Journal of Hazardous Materials 160: 514-520.

9. Durai G, Rajasimman M (2011) Biological treatment of tannery wastewater -a review. Journal of Environmental Science and Technology 4: 1-17.

10. Shakir L, Ejaz S, Ashraf M, Ahmad N, Javeed A (2012) Characterization of tannery effluent wastewater by proton-induced X-ray emission (PIXE) analysis to investigate their role in water pollution. Environmental Science and Pollution Research International 19: 492-501.

11. Iaconi CD, Lopez A, Ramadori R, Pinto ACD, Passino R (2002) Combined chemical and biological degradation of tannery wastewater by a periodic submerged filter (SBBR). Water Research 36: 2205-2214.

12. European Commission (2001) Reference Document on Best Available Techniques for the Tanning of Hides and Skins. Directorate-General Join Research Centre, Institute for Prospective Technological Studies (Seville), Technologies for Sustainable Development, European Integrated Pollution Prevention and Control (IPPC) Bureau, Spain.

13. Prasad BGS (1991) Treatment and disposal of waste-water for a tannery processing wet-blues to suede. Journal of the American Leather Chemists Association 86: 87-92.

14. Tare V, Sandeep G, Purnendu B (2003) Case Studies on Biological Treatment of Tannery Effluents in India, Journal of the Air and Waste Management Association 53: 976-982.

15. Ganesh R, Balaji G, Ramanujam RA (2006) Biodegradation of tannery wastewater using sequencing batch reactor-Respirometric assessment. Bio resource Technology 97: 1815-1821.

16. Cristina SC, Anto'nio OSS, Castro PML (2007) Constructed wetland systems vegetated with different plants applied to the treatment of tannery wastewater. Water research 41: 1790-1798.

17. Ayoub GM, Hamzeh A, Semerjian L (2011) Post treatment of tannery wastewater using lime/bittern coagulation and activated carbon adsorption. Desalination 273: 359-65.

18. Rajamani S, Shweta Singh, Ramasami T (2003) Sustainability and future scenario of the leather tanning SMEs on enforcement of environmental pollution control measures in developing countries. Leathers 19: 56-74.

19. Shanmugasundaram S, Murty DVS (2000) Performance evaluation of the common effluent treatment plant for tanneries at Pammal-Pallavaram Tamilnadu (India). Bioprocess Engineering 23: 431-434.

20. Tadesse I, Isoaho SA, Green FB, Puhakka JA (2003) Removal of organics and nutrients from tannery effluent by advanced integrated wastewater pond systems technology. Water Science and Technology 48: 307-314.

21. Carucci A, Chiavola A, Majone M, Rolle E (1999) Treatment of tannery wastewater in a sequencing batch reactor. Water Science and Technology 40 253-259.

22. Murat S, Genceli EA, Tasli R, Artan N, Orhon D (2002) Sequencing batch reactor treatment of tannery wastewater for carbon and nitrogen removal. Water Science and Technology 46: 219-227.

23. Artan N, Yagci NO, Artan SR, Orhon D (2003) Design of sequencing batch reactors for biological nitrogen removal from high strength wastewaters. Journal of Environmental Science and Health 38: 2125-2134. 
24. Iaconi CD, Bonemazzi F, Lopez A, Ramadori R (2004) Integration of chemical and biological oxidation in a SBBR for tannery wastewater treatment. Water Science and Technology 50: 107-114

25. Scholz WG, Rouge P, Bodalo A, Leitz U (2005) Desalination of mixed tannery effluent with membrane bioreactor and reverse osmosis treatment. Environmental Science and Technology 39: 8505-8511.

26. Ramanujam RA, Ganesh R, Mariappan M (2004) Biokinetics and toxicity assessment of tannery wastewater using batch reactor system. Journal of the American Leather Chemists Association 99: 468-473.

27. Ram B, Bajpai PK, Parwana HK (1999) Kinetics of chrome-tannery effluent treatment by the activated-sludge system. Process Biochemistry 35: 255-265.

28. Wang k, Li W, Gong X, Li X, Liu W, et al. (2014) Biological pretreatment of tannery wastewater using a full-scale hydrolysis acidification system. International Biodeterioration \& Biodegradation 95: 41-145.

29. Vidal G, Nieto J, Cooman K, Gajardo M, Bornhardt C (2004) Unhairing effluents treated by an activated sludge system. Journal of Hazardous Materials 112 143-149.

30. Leta S, Assefa F, Gumaelius L, Dalhammar G (2004) Biological nitrogen and organic matter removal from tannery wastewater in pilot plant operations in Ethiopia. Applied Microbiology and Biotechnology 66: 333-339.

31. Chung YJ, Choi HN, Lee SE, Cho JB (2004) Treatment of tannery wastewater with high nitrogen content using anoxic/oxic membrane bio-reactor MBR. Journal of Environmental Science and Health 39: 1881-1890.

32. Szpyrkowicz L, Kaul SN (2004) Biochemical removal of nitrogen from tannery wastewater: performance and stability of a full-scale plant. Journal of Chemical Technology and Biotechnology 79: 879-888.

33. Strous M, Heijnen JJ, Kuenen JG, Jetten MSM (1998) The sequencing batch reactor as a powerful tool for the study of slowly growing anaerobic ammoniumoxidizing microorganisms. Applied Microbiology and Biotechnology 50: 589596.

34. Roy S, Singha U, Goswami M, Roy A, Aich A, et al. (2013) Changes in physicochemical characteristics of wastewater carrying canals after relocation of Calcutta tannery agglomerates within the East Calcutta Wetland ecosystem. International Journal of Environmental Studies 70: 203-221.

35. Goltara A, Martinez J, Mendez R (2003) Carbon and nitrogen removal from tannery wastewater with a membrane bioreactor. Water Science and Technology 48: 207-214

36. Artiga P, Oyanedel V, Garrldo JM, Mendez R (2005) An innovative biofilmsuspended biomass hybrid membrane bioreactor for wastewater treatment. Desalination 179: 171-179.

37. Hulshoff LW, Lens PNL, Weijma J, Stams AJM (2001) New developments in reactor and process technology for sulphate reduction. Water Science and Technology 44: 67-76.

38. Song Z, Williams CJ, Edyvean RGJ (2003) Tannery wastewater treatment using an upflow anaerobic fixed biofilm reactor UAFBR. Environmental Engineering Science 20: 587-599.

39. Wiemann M, Schenk H, Hegemann W (1998) Anaerobic treatment of tannery wastewater with simultaneous sulphide elimination. Water Research 32: 774 780.

40. Genschow E, Hegemann W, Maschke C (1996) Biological sulfate removal from tannery wastewater in a two-stage anaerobic treatment. Water Research 30 2072-2078.

41. Lens PNL, Visser A, Janssen AJH, Hulshoff $P$, Lettinga $G$, et al. (1998) Biotechnological treatment of sulfate-rich wastewaters. Critical Reviews in Environmental Science and Technology 28: 41-88

42. Widdel $F$ (1988) Microbiology and ecology of sulphate and sulphur reducing bacteria. In: Zehnder AJB (eds.) Biology of Anaerobic microorganisms. Wiley \& Sons, New York, USA, pp: 469-586

43. Odum JM, Singleton R (1992) The sulphate-reducing bacteria: Contemporary Perspectives. Springer Verlag.

44. Widdel F, Pfennig N (1984) Dissimilatory sulfate or sulfur reducing bacteria. In: Kreig NR and Holt JG (eds.) Bergey's Manual of Systematic Bacteriology, Williams \& Wilkins, Baltimore, USA 1: 663-679.

45. Hamilton WA (1998) Bioenergetics of sulphate-reducing bacteria in relation to their environmental impact. Biodegradation 9: 201-212.
46. Parkin GF, Lynch NA, Kuo WC, Van-Keuren EL, Bhattacharya SK (1990) Interaction between sulfate reducers and methanogens fed acetate and propionate. Journal of Water Pollution Control Federation 62: 780-788.

47. Maillacheruvu KY, Parkin GF, Peng CY, Kuo WC, Oonge Zl, et al. (1993) Sulfide toxicity in anaerobic systems fed sulfate and various organics. Water Environment Research 65: 100-109.

48. McCartney DM, Oleszkiewicz JA (1993) Competition between methanogens and sulfate reducers: effect of COD: sulfate ratio and acclimation. Wate Environment Research 65: 655-664.

49. Visser A, Hulshoff $P$, Lettinga $G$ (1996) Competition of methanogenic and sulfidogenic bacteria, Water Science and Technology 33: 99-110.

50. Rinzema A, Lettinga G (1988) anaerobic treatment of sulfate containing waste water. Biotreatment systems Pp: 65-109.

51. Omil F, Mendez R, Lema JM (1995) Anaerobic treatment of saline wastewaters under high sulphide and ammonia content. Bioresource Technology 54: 269278

52. Garrels RM, Christ CL (1965) Solutions, Minerals and Equilibria, Harper \& Row, New York.

53. McCartney DM, Oleskiewicz JA (1991) Sulphide inhibition of anaerobic degradation of lactate and acetate. Water Research 25: 203-209.

54. Shin HS, Jung JY, Bae BU, Paik BC (1995) Phase separated anaerobic toxicity assays for sulphate and sulphide. Water Environment Research 67: 802-806.

55. Parkin GF, Sneve MA, Loos H (1991) Anaerobic filter treatment of sulfate containing wastewaters, Water Science and Technology 23: 1283-91.

56. Lens PNL, Kuenen JG (2001) The biological sulphur cycle: novel opportunities for environmental biotechnology. Water Science and Technology 44: 57-66.

57. Anderson GK, Donnelly T, McKeown KJ (1982) Identification and contro of inhibition in the anaerobic treatment of industrial wastewater. Process Biochemistry 17: 32-41.

58. Mizuno O, Li YY, Noike T (1998) The behaviour of sulphate-reducing bacteria in acidogeneic phase of anaerobic digestion. Water Research 32: 1626-1634.

59. Isa Z, Grusenmeyer S, Verstraete W (1986) Sulfate reduction relative to methane production in high-rate anaerobic digestion: Technical Aspects. Applied and Environmental Microbiology 51: 572-579.

60. Hilton BL, Oleszliewicz (1988) Sulphide induced inhibition of anaerobic digestion. Journal of Environmental Engineering 114: 1377-1391.

61. Zinder SH (1993) Physiological ecology of methanogens. Methanogens: Ecology, Physiology, Biochemistry and Genetics pp: 128-206.

62. Hansen TA (1993) Carbon metabolism of sulphate reducing bacteria. The sulphate reducing bacteria: Contemporary perspectives, pp: 21-40.

63. Rivers-Singleton JR (1993) The sulfate-reducing bacteria: an overview. The Sulfate-Reducing Bacteria: Contemporary Perspectives, pp: 1-20.

64. Mizuno O, Li YY, Noike T (1994) Effects of sulphate concentration and sludge retention time on the interaction between methane production and sulphate reduction for butyrate. Water Science and Technology 30: 45-54.

65. Uberoi VU, Bhattacharya SK (1995) Interaction among sulphate reducers, acetogens and methanogens in anaerobic propionate systems. Water Environment Research 67: 330-339.

66. Lovley DR, Phillips EJP (1987) Competitive mechanisms of sulfate reduction and methane production in the zone of ferric iron reduction in sediments. Applied and Environmental Microbiology 53: 2636-2641.

67. Tursman JF, Cork DJ (1989) Influence of sulphate and sulphate reducing bacteria on anaerobic digestion technology. Biological Waste Treatment, pp: 273-281.

68. Cord-Ruwisch R, Steitz HJ, Conrad R (1988) The capacity of hydrogenotrophic anaerobic bacteria to compete for traces of hydrogen depends on the redox potential of the terminal electron acceptor. Archives of Microbiology 149: 350357.

69. Gupta A, Joseph RV, Flora L, Gupta M, Gregory DS, et al. (1994) Methanogenesis and sulfate reduction in chemostats-kinetic studies and experiments. Water Research 28: 781-793.

70. Frostell B (1982) Anaerobic fluidized bed experimentation with molasses waste water. Process Biochemistry 17: 37-40. 
71. Meyer-Jens T, Matz G, Markl H (1995) On-line measurement of dissolved and gaseous hydrogen sulphide in anaerobic biogas reactors. Applied Microbiology and Biotechnology 43: 341-345.

72. Fox P, Venkatasubbiah $\vee(1996)$ Coupled anaerobic/aerobic treatment of highsulphate wastewater with sulphate reduction and biological sulphide oxidation. Water Science and Technology 34: 359-366.

73. Khanal SK, Huang JC (2003) ORP-based oxygenation for sulphide control in anaerobic treatment of high-sulphate wastewater. Water Research 37: 2053-2062.

74. Visser A, Alphenaar PA, Gao Y, van-Rossum G, Lettinga, G (1993) Granulation and immobilisation of methanogenic and sulfate-reducing bacteria in high-rate anaerobic reactors. Applied Microbiology and Biotechnology 40: 575-581.

75. Alphenaar PA, Visser A, Lettinga G (1993) The effect of liquid upward velocity and hydraulic retention time on granulation in UASB reactors treating wastewater with a high sulphate content. Bioresearch Technology 43: 249-258.

76. Sliekers AO, Derwort N, Gomez JLC, Strous M, Kuenen JG, et al. (2002) Completely autotrophic nitrogen removal over nitrite in one single reactor. Water Research 36: 2475-2482.

77. Avila JR, Flores ER, Gomez J (2004) Simultaneous biological removal of nitrogen, carbon and sulfur by dinitrification. Water Research 38: 3313-3321.

78. Mulder A, van-de Graaf AA, Robertston LA, Kuenen JG (1995) Anaerobic ammonium oxidation discovered in a denitrifying fluidized bed reactor. FEMS Microbiology and Ecology 16: 177-183.

79. Teixeira P, Oliveira R (2000) Denitrification by Alcaligenes denitrificans in a closed rotating biological contactor. Biotechnology Letters 22: 1789-1792.

80. Carrera J, Vincent T, Lafuente J (2004) Effect of influent COD/N ratios on biological nitrogen removal (BNR) from high-strength ammonium industrial wastewater. Process Biochemistry 39: 1615-1624.

81. Koops HP, Bottcher B, Moller UC, Stehr G (1991) Classification of eight new species of ammonia oxidizing bacteria. Journal of Genetic Microbiology 137 1689-1699.

82. Horan NJ (1996) Biological Wastewater Treatment Systems-Theory and Operation. John Wiley \& Sons, New York, USA.

83. USEPA (1993) Office of Research and Development, Office of Water-Nitrogen Control Manual. EPA/625/R-93/010, United States Environmental Protection Agency, Washington DC, USA.

84. Metcalf E (2001) Wastewater Engineering: Treatment and Reuse, 4th edition, Tata McGraw-Hill, New Delhi.

85. Khin T, Annachhatre AP (2004) Novel microbial nitrogen removal processes Biotechnology Advances 22: 519-532.

86. Jetten MSM, Logemann S, Muyzer G, Robertson LA, de-ries S, et al. (1997) Novel principles in the microbial conversion of nitrogen compounds. Antonievan Leeuwenhoek 71: 75-93.

87. Ballinger SJ, Head IM, Curtis TP, Godley AR (2002) The effect of C/N ratio on ammonia oxidizing bacteria community structure in a laboratory nitrificationdenitrification reactor. Water Science and Technology 46: 543-550.
88. Henze M (1991) Capabilities of biological nitrogen removal processes from wastewater. Water Science and Technology 23: 669-679.

89. Kuenen JG, Robertson L A (1994) Combined nitrification- denitritication processes. FEMS Microbial Reviews 15: 109-117.

90. Koenig A, Zhang T, Liu LH, Fang HHF (2005) Microbial community and biochemistry process in autosulphurotrophic denitrifying biofilm. Chemosphere 58: 1041-1047.

91. Lee KC, Rittmann BE (2000) A novel hollow-fibre membrane biofilm reacto for autohydrogenotrophic denitrification of drinking water. Water Science and Technology 41: 219-226.

92. Van-de Graaf AA, De-Bruijn P, Robertson LA, Jetten MSM, Kuenen JG (1996) Autotrophic growth of anaerobic ammonium-oxidizing micro-organisms in a fluidized bed reactor. Microbiology 42: 2187-2196.

93. Strous M, Van-Gerven E, Ping Z, Kuenen JG, Jetten MSM (1997) Ammonium removal from concentrated waste streams with the Anaerobic Ammonium Oxidation (ANAMMOX) process in different reactor configurations. Water Research 31: 1955-1962.

94. Dapena-Mora A, Campos JL, Mosquera-Corral A, Jetten MSM, Mendez R (2004) Stability of the ANAMMOX process in a gas-lift reactor and a SBR. Journal of Biotechnology 110: 159-170.

95. Van-Dongen U, Jetten MSM, Van-Loosdrecht MCM (2001) The SHARONANAMMOX process for treatment of ammonium rich wastewater. Water Science and Technology 44: 153-160.

96. Schalk J, Oustad H, Kuenen JG, Jetten MSM (1998) The anaerobic oxidation of hydrazine-a novel reaction in microbial nitrogen metabolism, FEMS Microbiology Letters 58: 61-67.

97. Wang J, Kang J (2005) The characteristics of anaerobic ammonia oxidation (Anaerobic Ammonia Removal) by granular sludge from an EGSB reactor Process Biochemistry 40: 1973-1978.

98. Ahn YH (2006) Sustainable nitrogen elimination biotechnologies: A review. Process Biochemistry 41: 1709-1721.

99. Polanco FF, Polanco MF, Fernandez N, Uruena MA, Garcia PA, et al. (2001) New process for simultaneous removal of $\mathrm{N}$ and sulphur under anaerobic conditions. Water Research 35: 1111-1114.

100. Sabumon PC (2008) Development of the sulphidogenesis cum ammonia removal process for treatment of tannery effluent. Water Science and Technology 58: 391-397.

101. Sabumon PC (2008) Development of a novel process for ammonia removal with sulphidogenesis, Process Biochemistry 43: 984-991.

102. Colleran E, Finnegan S, Lens P (1995) Anaerobic treatment of sulphatecontaining waste streams. Antonievan Leeuwenhoek 67: 29-46.

103. Karhadkar PP, Audice JM, Faup GM, Khanna P (1987) Sulphide and sulphate inhibition of methanogenesis. Water Research 21: 1061-1066. 